Int. J. Electrochem. Sci., 12 (2017) $6566-6576$

International Journal of

ELECTROCHEMICAL

SCIENCE

www.electrochemsci.org

\title{
Electrochemical Synthesis of a Binary Mn-Co Oxides Decorated Graphene Nanocomposites for Application in Nonenzymatic $\mathrm{H}_{2} \mathrm{O}_{2}$ Sensing
}

\author{
Su-Juan Li ${ }^{*}$ Yun Xing, Hong-Yuan Yang, Jia-Yan Huang, Wen-Tian Wang, Rui-Ting Liu \\ Henan Province Key Laboratory of New Optoelectronic Functional Materials, College of Chemistry \\ and Chemical Engineering, Anyang Normal University, Anyang, 455000, Henan, China. \\ *E-mail: lemontree88@163.com
}

doi: $10.20964 / 2017.07 .55$

Received: 12 April 2017 / Accepted: 11 May 2017 / Published: 12 June 2017

In this work, binary metallic oxides of $\mathrm{MnO}_{2}-\mathrm{Co}_{3} \mathrm{O}_{4}$ nanocomposite was electrodeposited on graphene oxide (GO) modified electrode by a facile and one-step electrochemical method. The resultant $\mathrm{MnO}_{2}-$ $\mathrm{Co}_{3} \mathrm{O}_{4} /$ graphene $\left(\mathrm{MnO}_{2}-\mathrm{Co}_{3} \mathrm{O}_{4} / \mathrm{GP}\right)$ electrode was characterized by scanning electron microscopy (SEM) and energy dispersive X-ray spectroscopy (EDX) to study its morphology and element composition. The as-prepared $\mathrm{MnO}_{2}-\mathrm{Co}_{3} \mathrm{O}_{4} / \mathrm{GP}$ modified electrode was employed in fabricating a nonenzymatic $\mathrm{H}_{2} \mathrm{O}_{2}$ electrochemical sensor. The cyclic voltammetry $(\mathrm{CV})$ and amperometric experiments demonstrated that the $\mathrm{MnO}_{2}-\mathrm{Co}_{3} \mathrm{O}_{4} / \mathrm{GP}$ composites exhibited superior electrocatalytic activities toward oxidation of $\mathrm{H}_{2} \mathrm{O}_{2}$ to the monometallic oxide decorated graphene materials $\left(\mathrm{MnO}_{2} / \mathrm{GP}\right.$ and $\mathrm{Co}_{3} \mathrm{O}_{4} / \mathrm{GP}$ ). The developed nonenzymatic $\mathrm{H}_{2} \mathrm{O}_{2}$ sensor showed a high sensitivity of $53.65 \mu \mathrm{AmM}$ ${ }^{1} \mathrm{~cm}^{-2}$, a wide linear range of $5 \mu \mathrm{M}-1.2 \mathrm{mM}$, and a detection limit of $0.8 \mu \mathrm{M}(\mathrm{S} / \mathrm{N}=3)$. In addition, good selectivity, high detection accuracy and acceptable stability were also obtained for the present sensor. Therefore, this work will open an avenue to construct high-performance electrode materials and expand their applications in various fields such as catalysis and biosensor.

Keywords: Electrochemical; Graphene; binary metallic oxides; Hydrogen peroxide

\section{$\underline{\text { FULL TEXT }}$}

(C) 2017 The Authors. Published by ESG (www.electrochemsci.org). This article is an open access article distributed under the terms and conditions of the Creative Commons Attribution license (http://creativecommons.org/licenses/by/4.0/). 